TITLE:

\title{
ON TWO NEW SPECIES OF PALAEMONID SHRIMPS FROM TANABE BAY, KII PENINSULA, JAPAN (CRUSTACEA, DECAPODA, PALAEMONIDAE)
}

\section{$\operatorname{AUTHOR}(S)$ :}

Fujino, Takahiro; Miyake, Sadayoshi

\section{CITATION:}

Fujino, Takahiro ... [et al]. ON TWO NEW SPECIES OF PALAEMONID SHRIMPS FROM TANABE BAY, KII PENINSULA, JAPAN (CRUSTACEA, DECAPODA, PALAEMONIDAE).

PUBLICATIONS OF THE SETO MARINE BIOLOGICAL LABORATORY 1969, 17(3): 143-154

\section{ISSUE DATE:}

1969-11-29

URL:

http://hdl.handle.net/2433/175597

RIGHT: 


\title{
ON TWO NEW SPECIES OF PALAEMONID SHRIMPS FROM TANABE BAY, KII PENINSULA, JAPAN (CRUSTACEA, DECAPODA, PALAEMONIDAE) $)^{1)}$
}

\author{
TAKahiro FUJINO and Sadayoshi MIYAKE \\ Zoological Laboratory, Faculty of Agriculture, Kyushu University
}

With 5 Text-figures

From the collection of shrimps recently obtained in the shallow waters of Tanabe Bay, Kii Peninsula we sorted out some interesting palaemonid shrimps. After a careful examination, they proved to be referable to two new species, Leandrites cyrtorhynchus of the subfamily Palaemoninae and Periclimenes (Periclimenes) setoensis of Pontoniinae. Although the genus Leandrites Holthuis has been recorded from South India and the Malay Archipelago it is here first added to the palaemonid fauna of Japan, in which only three genera of the Palaemoninae, Palaemon Fabricius, Leander Desmarest and Macrobrachium Bate, are well known. Regarding the latter pontoniid shrimp, Periclimenes (Periclimenes) setoensis, its habit was to some extent made clear; the specimens examined were found living in close association with an alcyonarian. This fact is worthy to be noted because only a few pontoniid shrimps have been known to be associated with this host animal.

These type specimens are deposited in the Zoological Laboratory of Kyushu University (ZLKU) and the museum of the Seto Marine Biological Laboratory (SMBL).

It is a pleasure to thank Prof. Huzio Utinomi and Mr. Chuichi Araga of the Seto Marine Biological Laboratory, for the opportunity to examine their valuable material.

\section{Leandrites cyrtorhynchus sp. nov.}

(Figs. 1-3)

Diagnosis. Rostrum slender, long, strongly upcurved and provided with two strong teeth over orbit and smaller ones on both upper and lower borders. Stout epigastric spine present. Branchiostegal spine distinctly apart from anterior margin

1) Contributions from the Zoological Laboratory, Faculty of Agriculture, Kyushu University, No. 397 and Contributions from the Seto Marine Biological Laboratory, No. 509.

Publ. Seto Mar. Biol. Lab., XVII (3), 143-154, 1969. (Article 5) 
of carapace. Pleuron of fifth abdominal segment produced backwards in narrow lobe. Telson with two pairs of very small dorsal spines; anterior pair placed behind the middle. Mouthparts normal; epipod of first maxilliped distinctly bilobed; third maxilliped slender and long. Anterolateral corner of antennular basal segment produced forwards roundly; stylocerite short and pointed. Fingers of first pereiopod narrow and as long as palm. Fingers of second pereiopods slender and subequal to palm in length, with several inconspicuous teeth on cutting edges proximally. Last

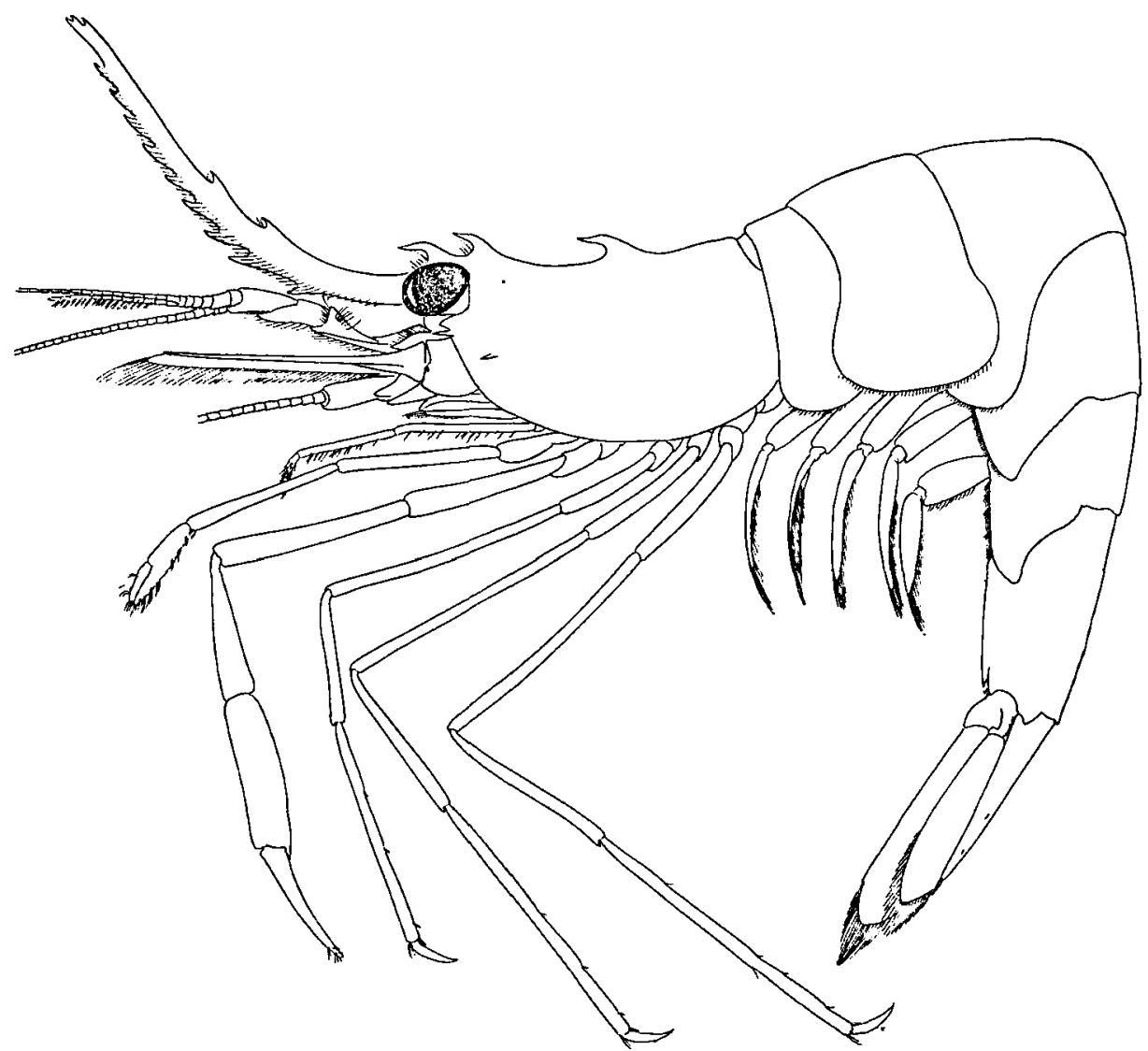

Fig. 1. Leandrites cyrtorhynchus sp. nov., $\times 5$.

three pereiopods slender; dactylus rather stout, short and slightly curved; propodus with spinules on posterior border.

Description of holotype. The rostrum is slender and very long, reaching far beyond the end of the antennal scale (Fig. I). It is strongly upcurved and becomes gently tapered towards the apex. The upper border bears six teeth excluding a strong epigastric tooth on the carapace; the first tooth is situated a little behind the orbit, 
and the second, which is the strongest of the six, over the eyestalk and close to the first; the third tooth small, near the middle of the rostrum and apart considerably from the second; the interval between the third and the fourth teeth is less than a half of the distance between the second and the third; a much larger space between the fourth and the fifth teeth; both the fifth and the sixth teeth are very small and close to the apex. The tip of the proximal two teeth is bent anteriorly, while the others are nearly straight. Some plumose setae are found before each of the first to the fourth teeth. On the lower border of the rostrum there are nine teeth, which gradually decrease the size distally; the first tooth is at the proximal third of the rostrum; the distance between the first and the second teeth is much larger than the other intervals; the distal tooth is placed somewhat posterior to the level of the upper distal teeth. A double fringe of plumose setae is present along the lower border of the rostrum from near the base to the interval between the two distal teeth; these setae are placed on either side of the rostrum slightly above the bases of the lower teeth. A distinct lateral carina is absent.

The carapace is compressed and smooth, a little less than one and a half as long as broad. The orbital angle is produced forwards to form a short, round lobe. The antennal spine is strong and placed a short distance behind the orbital angle. The branchiostegal spine is shorter than the antennal and is situated at some distance behind the anterior margin of the carapace and at the level considerably lower than the antennal spine. The anterolateral corner of the carapace is broadly rounded, not forming an angle.

The pleura of the first three abdominal segments are smoothly rounded. The posterodorsal part of the third segment is more or less expanded backwards roundly. The pleuron of the fourth segment is narrowly produced at the posteroventral corner, and that of the fifth is produced at the same corner acutely to form a narrow, bluntly pointed lobe strongly extended backwards. The sixth segment is somewhat elongated and a little less than twice the length of the fifth segment.

The telson is slender and slightly shorter than the sixth abdominal segment (Fig. 2, b). It tapers gently to an angular tip. The upper surface is longitudinally convex, especially in the proximal portion and is provided with two pairs of small spines which are set shortly apart from the lateral margins; the anterior pair is placed a little posterior to the middle of the telson; the posterior pair is midway between the anterior pair and the hind end of the telson. The hind end of the telson is provided with three pairs of terminal spines; the outer pair is minute; the median is the longest and strongest and measures one-seventh of the length of the telson; the inner pair is very slender and less than half as long as the median, with many soft hairs.

The cornea is swollen, globular and well pigmented. The ocellus is indistinct, because it is completely fused with the cornea. The peduncle is much slenderer but somewhat longer than the cornea. 
The basal segment of the antennular peduncle is broad, the outer margin being almost straight and ending anteriorly in a distinct terminal spine (Fig. 2, a); the anterolateral corner is protruded into a lobe with the narrow rounded top which nearly attains the middle of the second segment beyond the tip of the terminal spine of the outer margin. The stylocerite is short and fails to reach the middle of the basal segment; very broad in the basal portion and abruptly narrowed to a sharply pointed tip. The second segment is short and provided laterally with a narrow lobe extended forwards. The basal and the second segments bear each many plumose setae along both the lateral and the anterior margins. The third segment is cylindrical and stout, and almost as long as the second. The distal two segments together are somewhat shorter than the basal segment. The outer antennular flagellum has

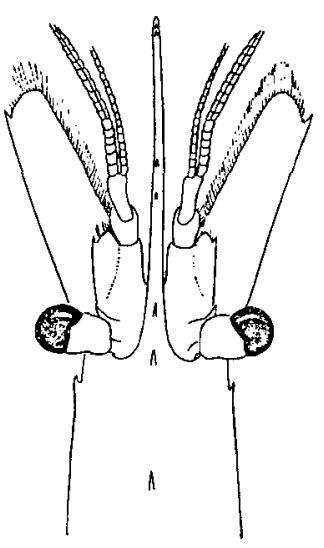

$a$

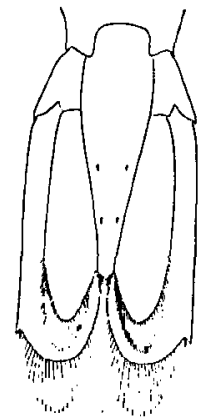

$b$

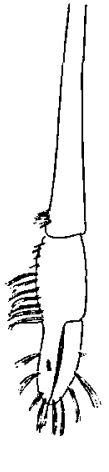

$c$

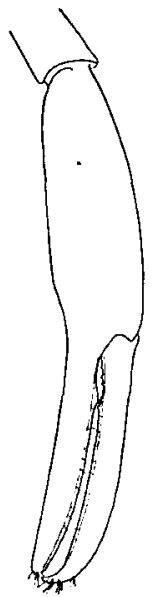

$d$
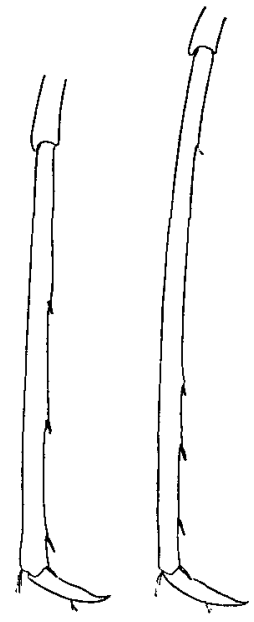

e $f$

Fig. 2. Leandrites cyrtorhynchus sp. nov. $a$, Anterior part of body in dorsal view, $\times 4 ; b$, telson and uropods, $\times 5.6 ; c$, chela of first pereiopod, $\times 8.4 ; d$, chela of second pereiopod, $\times 8.4 ; e$, distal part of third pereiopod, $\times 8.0 ; f$, distal part of fifth pereiopod, $\times 8.0$.

the two rami fused for six joints; the free portion of the shorter ramus is more than twice as long as the fused portion.

The antennal scale is broad and about three times as long as its maximum breadth; the anterior margin of the lamella is convex but rather truncated, much exceeding the end of the antennular peduncle; the outer lateral margin is nearly straight and terminates in a strong, lateral spine which falls short of the end of the lamella. The basicerite of the antennal peduncle is armed laterally with a small spine. The carpocerite is stout and cylindrical, the tip extending to the end of the basal segment of the antennular peduncle.

The mouthparts are typical of the genus. The mandible lacks the palp (Fig. 
$3, a)$; the molar process bears six strong, irregular processes and a small tuft of fine setae; the incisor process is rather broad and has three stout teeth distally. The palp of the maxillule is distinctly bilobed into the larger part with a strongly crooked tip and the smaller part (Fig. 3,b); the distal endite is somewhat broad with strong setae at the distal margin; the proximal endite is shorter and narrower than the distal, situated close to it, and with many fine setae at the end. The endite of the maxilla is deeply cleft for half the length and with long thin setae (Fig. 3,c); the palp is well developed and non-setose; the scaphognathite is rather narrow and fringed marginally with plumose hairs. The broad endite of the first maxilliped is divided by a shallow notch into a larger, upper and a smaller, lower parts (Fig. 3, d); the palp is well developed, with a single seta at the middle of the outer margin, and becomes narrower in the distal half; the caridean lobe of the exopod is broad and round, plumose setae fringing the outer margin; the bilobed epipod is well-developed, the distal lobe being much larger than the proximal. The second maxilliped is of typical shape (Fig. 3,e); a large podobranch and the rather narrow but well-developed epipod are present. The third maxilliped is slender and pediform (Fig. 3, $f$ ); the ultimate segment is cylindrical and attenuated towards the pointed tip, being covered with setae set singly or in tufts; the penultimate segment is a little less than twice as long as the ultimate, very slender and provided with a series of stout setae along the posterior border; the antepenultimate segment is also slender but somewhat stouter than the distal two segments and about one and a half as long as the penultimate; the exopod is rather short and falls short of the end of the antepenultimate; the epipod is thin and round with the narrow top; a small arthrobranch and a welldeveloped pleurobranch are present.

The fingers of the first pereiopod are narrow and as long as the palm, and each provided with several tufts of long hairs, (Fig. 2,c); the cutting edges are thin and entirely smooth. The palm is provided on the inner border with a narrow row of long setae. The carpus is subcylindrical and somewhat heavy distally, more or less longer than one and a half the length of the chela. Near the inner distal portion of the carpus there is a tuft of setae set transversely. The merus is slender, cylindrical, and is equal to the carpus in length. The ischium is much stouter and slightly shorter than a half of the merus.

The second pereiopods are symmetrical, exceeding the end of the antennular peduncle by the length of the chela and the carpus together (Fig. 2, $d$ ). The fingers are long and slender, the tips being strongly hooked and crossed when closed; the cutting edge of the movable finger is thin and entire except for several obscure teeth in the proximal half; a small tooth is also placed at the proximal third on the cutting edge of the immovable finger. The palm is not much swollen, a little less than three times as long as broad, and subequal to the fingers in length. The carpus is subcylindrical and becomes thicker distally, and equal to the palm in length, the distal margin being entire but a shallow notch situated proximally. The merus and the 
ischium are elongated and rather cylindrical, and subequal in length, somewhat longer than the carpus.

The last three pereiopods are slender and almost similar to one another, though becoming somewhat longer posteriorly (Fig. $e, f$ ). The dactylus is slightly curved, rather stout, sharply pointed at the tip, and with some setae at the middle on the anterior margin. The propodus is more than seven times as long as the dactylus, straight and excessively narrow, and bears one pair of spinules on the distal margin and three or four spinules on the proximal border. The carpus is as broad as and shorter than half the length of the propodus. The merus is slightly stouter than

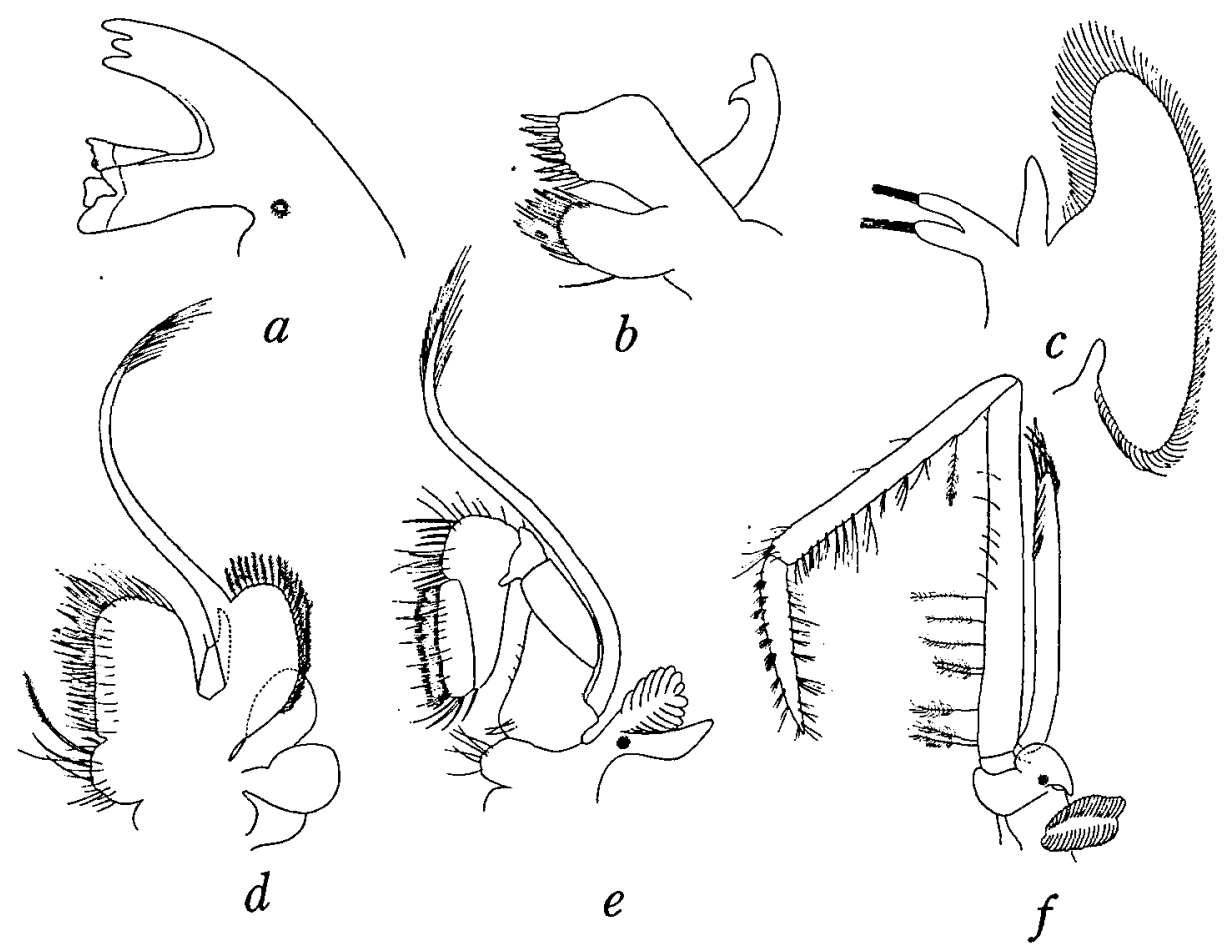

Fig. 3. Leandrites cyrtorhynchus sp. nov. $a$, Mandible; $b$, maxillule; $c$, maxilla; $d$, first maxilliped; $e$, second maxilliped; $f$, third maxilliped.

the distal segments and a little shorter than the propodus. Both the carpus and the merus are devoid of any spines or hairs.

The pleopods are normal in shape. The endopod of the first pleopod is short, narrow, and with many plumose hairs along the outer margin. The appendix interna of the second pleopod is long, the tip extending beyond the middle of the endopod.

The uropods far exceed the end of the telson. The exopod is much longer than the endopod, the outer margin being nearly straight and ending in a small spine accompanied with a longer movable one just inside. 
Size. Holotype: body length $30.7 \mathrm{~mm}$, carapace length $6.0 \mathrm{~mm}$, rostrum length $11.0 \mathrm{~mm}$, telson length $4.8 \mathrm{~mm}$, chela of second pereiopod $6.3 \mathrm{~mm}$ long, movable finger of second pereiopod $3.0 \mathrm{~mm}$ long.

Type. Holotype, +, SMBL Type 230, Tô-shima I., Tanabe Bay, Wakayama Pref., July 19, 1963, C. Araga leg.

Remarks. The new species is easily distinguished from the other three of the genus Leandrites by its excessively slender and strongly upcurved rostrum and the existence of a stout epigastric spine. Moreover, the ambulatory pereiopods of the new species are slender but rather stout, while in the other species they are very slender and filiform, especially the dactylus is much narrower and its proportional length is distinctly larger than in the new species. The new species has a pair of spinules on the posterodistal margin and three or four additional ones on the posterior border of the last three pereiopods. On the contrary, in the previously known species the last two pereiopods are entirely devoid of any spinules save for only scattered hairs, though the third is provided with some spinules. Therefore, so far as the arrangement of the spinules on the ambulatory .pereiopods is concerned, the present new species seems to show a feature more closely related to the species of the genus Leander Desmarest which has spines on all of the last three pereiopods than to those of Leandrites Holthurs. However, Leandrites is definitely separable from Leander by that the former is devoid of the palp on the mandible.

In the external features the new species bears a strange resemblance to Leander uracaridella Holthuss, 1950, though the latter is apparently distinguishable from the former by the possession of the much longer and slender dactylus.

The known species of Leandrites are all recorded from the rather shallow, often brackish waters of South India and the Malay Archipelago. So, the occurrence of the new species in Tanabe Bay has extended the distributional range of the genus northwards to Japan. The genus Leandrites is thus an addition, as the fourth genus, to the already known genera of Palaemoninae from Japan, i.e., Palaemon FAbricius and Leander Desmarest both inhabiting the shallow, coastal or fresh waters and Macrobrachium BATE from the fresh-water environment.

Periclimenes (Periclimenes) setoensis sp. nov.

(Figs. 4, 5)

Diagnosis. Rostrum almost straight and rather shallow with eight or nine teeth on upper border; first tooth above orbit. One or two teeth of smaller size on lower border. Telson elongated with two pairs of dorsal spines; the anterior placed at the middle and the posterior halfway between the anterior pair and the distal end of telson. Antennal scale broad, end of lamella exceeds lateral tooth. Mouthparts typical; first maxilliped with triangular epipod. Fingers of first pereiopod a little shorter than palm, with entire cutting edges. Second pereiopods almost symmetrical; 
fingers slender and straight with long setae, without teeth on cutting edges; palm slender, cylindrical and as long as fingers. Carpus more than half the length of palm. Dactyli of last three pereiopods slender and biunguiculated; anterior claw less than half the length of basal part.

Description of holotype. The rostrum is almost straight, the pointed apex extending somewhat beyond the end of the third segment of the antennular peduncle (Fig. 4). On the upper border there are nine teeth, which show indistinctly a trend of slight bending down towards the apex; the first tooth is above the orbit, and the distal one near the apex is small. The teeth interval becomes smaller from the distal

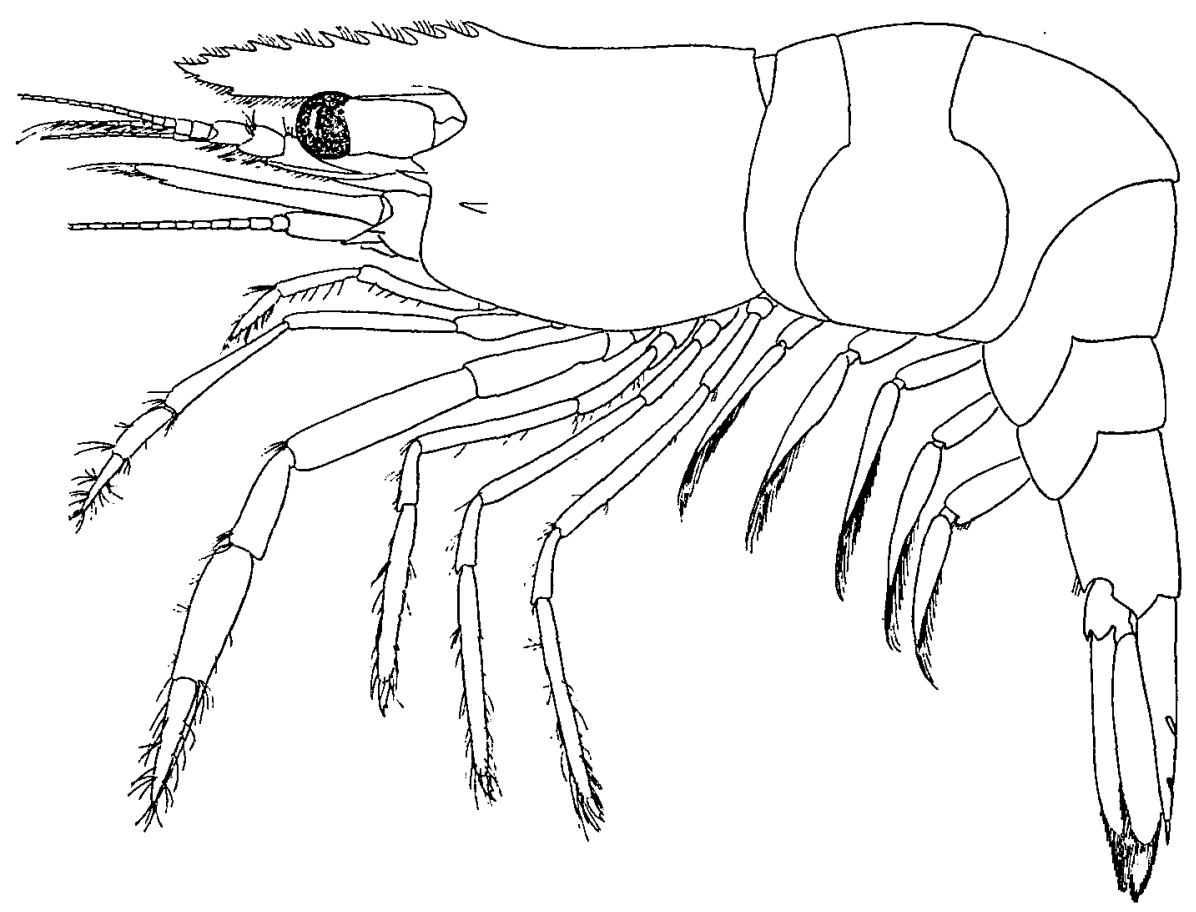

Fig. 4. Periclimenes (Periclimenes) setoensis sp. nov., $\times 12.6$.

fourth tooth towards both the ends. On the lower border two small teeth are present below the upper, distal and the second distal teeth respectively.

The carapace is smooth. The orbital angle is produced forwards into a triangular lobe. The antennal and the hepatic spines are strong and subequal in length, the latter is situated at a distance to and at the level slightly lower than the former. The anterolateral corner of the carapace is somewhat right angled.

The abdominal segments are all smooth. The pleura of the first three segments are broadly rounded, while the next two are narrowly extended posteroventrally. The sixth segment is more than one and a half the length of the fifth segment. 
The telson is elongated, three and a half times as long as broad, and a little less than one and a half the length of the sixth abdominal segment (Fig. 5, b). The upper border bears two pairs of distinct dorsal spines; the anterior pair rises at the middle of the telson and the posterior is placed halfway between the anterior pair and the hind end of the telson; these spines are set somewhat apart from the lateral margins. Of three pairs of terminal spines the outer is small but distinct, the median is stout and long, and the inner slender and about half as long as the median.

The cornea is hemispherical, a small ocellus being faintly visible near the corneal border. The peduncle is longer and a little broader than the cornea.

The basal segment of the antennular peduncle is broad (Fig. 5, a); the outer margin is slightly convex, ending distally in a stout lateral spine reaching as far as the end of the second segment; the anterolateral corner is produced roundly, extending nearly to the middle of the second segment. The stylocerite is slender with a sharply pointed tip which extends beyond the level of the middle of the basal segment. The distal two segments are short, the second being a little broader and shorter than the third. The distal two segments together are about half the length of the basal. The outer antennular flagellar rami are fused for three joints; the shorter free portion is about twice as long as the fused one.

The antennal scale is broad and more than two and a half times as long as the maximum breadth; the outer lateral margin is almost straight and ends distally in a strong lateral tooth which is far exceeded by the end of the lamella. The anterior margin of the lamella is strongly convex roundly. The basicerite of the antennal peduncle has laterally a distinct tooth. The carpocerite is rather short and cylindrical, falling short of the middle of the antennal scale.

The mouthparts are typical of the genus. The incisor process of the mandible has distally four stout teeth; the molar process bears blunt knobs and edges with brush-like arranged bristles (Fig. 5,c). The palp of the maxillule is shallowly notched. The scaphognathite of the maxilla is broad, and the endite is separated by a deep notch. The epipod of the first maxilliped is well developed and triangular (Fig. $5, d)$; the caridean lobe of the exopod is broad and with the circular outer margin. The ultimate segment of the third maxilliped is shorter than the penultimate, both bearing many tufts of coarse setae (Fig. 5,e); the antepenultimate segment is one and a quarter times the length of the ultimate; the exopod never reaches the end of the antepenultimate; the epipod is round; a small arthrobranch is present.

The first pereiopod exceeds the end of the lamella of the antennal scale by the length of the movable finger when extended anteriorly (Fig. 5, $f$ ). The fingers are narrow, with the cutting edges entire. The palm is somewhat longer than the fingers. Some tufts of setae are present distally on the chela. The carpus is cylindrical and increases the thickness towards the distal portion. The merus is subcylindrical and distinctly longer than the carpus.

The second pereiopods are almost symmetrical but a trifle unequal in length 
(Fig. 5, $g, h$ ). The fingers are elongated, straight and similar to each other; the maximum breadth is found around the middle; the outer margins are gently curved; both the tips are nearly straight in the larger pair but crooked in the smaller; the cutting edges are straight and smooth without tooth or serration. The palm is rather slender and cylindrical, as long as the fingers. Long hairs grow on the chela. The carpus is short and round in cross section, the proximal part being slender; the

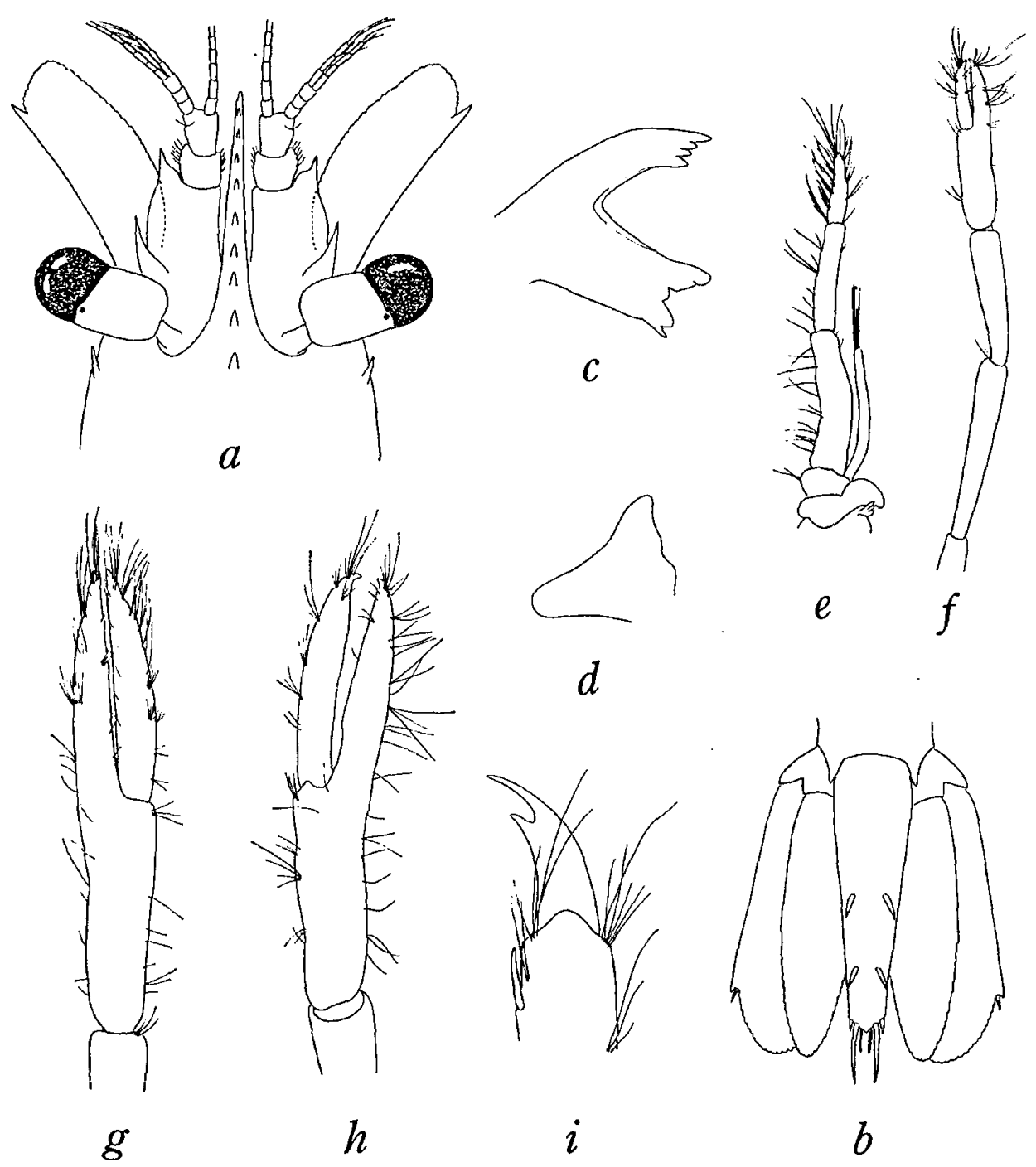

Fig. 5. Periclimenes (Periclimenes) setoensis sp. nov, a, Anterior part of body in dorsal view, $\times 19.5$; h. telson and uropods, $\times 19.5$; $c$, mandible; $d$, epipod of first maxilliped; $e$, third maxilliped; $f$, first pereiopod, $\times 26 ; g$, chela of second left pereiopod, $\times 26 ; h$, chela of second right pereiopod, $\times 26 ; i$, dactylus of third pereiopod, $\times 77.5$. 
distal margin is smooth, but with a shallow notch inside. The carpus is more or less slenderer and longer in the smaller pair than in the larger. The merus is twice as long as the carpus. The ischium is somewhat shorter than the merus.

The last three pereiopods are rather slender and similar to one another. The dactylus is curved and biunguiculated, gently narrowed distally (Fig. 5, i); the breadth of the basal portion of the anterior claw is one-third of the length from the base to the tip of the claw; the anterior claw is a little shorter than a half of the maximum length of the basal part. The propodus is slender and straight, with several spinules on the posterjor border and long setae on both the anterior and the posterior borders. The merus of the third pereiopod is as long as the propodus, but the former is shorter than the latter in the fifth. Long hairs are dispersed on both the carpus and the merus.

The pleopods are normal.

The uropods are longer than the telson. The outer margin of the exopod is straight and ends in a minute spine accompanied with a longer one inside.

Size. Holotype: body length $10.5 \mathrm{~mm}$, carapace length $2.2 \mathrm{~mm}$, rostrum length $2.3 \mathrm{~mm}$, telson length $1.8 \mathrm{~mm}$, chela of second right pereiopod $2.2 \mathrm{~mm}$ long, chela of second left pereiopod $2.0 \mathrm{~mm}$ long, movable finger of second right pereiopod $1.1 \mathrm{~mm}$ long, movable finger of second left pereiopod $1.0 \mathrm{~mm}$ long; paratypes: three specimens measure respectively $0.9 \mathrm{~mm}, 1.1 \mathrm{~mm}$ and $1.6 \mathrm{~mm}$ in carapace length.

Types. Holotype, ㅇ, SMBL Type 231; paratypes, 3 우, ZLKU No. 11110 , Shisô-jima I., Tanabe Bay, Wakayama Pref., 5 m deep, Nov. 23, 1951, H. Uтімом leg.

Remarks. This new species shows a close alliance with Periclimenes (Periclimenes) incertus BorradaIle, 1915, but the former is mainly separable from the latter by the shape and the proportional length of the fingers as well as the carpus and merus of the second pereiopods; in P. (P.) incertus, according to KEMP (1922) who originally recorded it under the name of Periclimenes (Periclimenes) impar and Holthurs (1952), a broad excavation is present in the middle of each cutting edge of the fingers of the second pereiopods, while in the new species the cutting edges are nearly straight so as to meet almost throughout their length when closed; these fingers of the new species are as long as the palm, whereas they are two-thirds as long as the palm in $P$. (P.) incertus; the proportional length of the carpus and the ischium of the new species is much larger than in $\dot{P}$. $(P$. $)$ incertus. Furthermore, the dactylus of the last three pereiopods of the new species is distinctly narrower and both the anterior and the posterior claws are spaced much less than in $P$. $(P$.) incertus. In addition, the differences in the shape and the arrangement of the upper teeth on the rostrum between the two species are to be noted; the almost straight upper margin and the site of the first tooth on the orbit in the new species differ clearly from the corresponding aspects of $P$. $(P$. $)$ incertus, in which the upper margin is convex and the first tooth is distinctly 
situated on the carapace behind the level of the orbit.

The specimens of the new species were collected in association with an alcyonarian, Dendronephthya disciformis KüKentHal in depth of about $5 \mathrm{~m}$. It has been known that the alpheid shrimp, Synalpheus gravieri Coutiére, is usually found associated with this alcyonarian. So, the association of the present new species with this host is a new addition to the cases of the commensal relation between alcyonarians and palaemonid shrimps hitherto be known in the other two Indo-Pacific species, Periclimenes (Periclimenes) investigatoris KEMP, 1922 and P. (Harpilius) diversipes KEMP, 1922. P. (P.) investigatoris looks in general features like the new present species, but the former is easily distinguishable from the latter by the much longer stylocerite reaching forwards as far as the articulation of the second segment of the antennular peduncle and by the distictly dentated fingers of the second pereiopods in the former. $P$.(H.) diversipes has the simple dactyli of the ambulatory pereiopods, and this subgeneric character is a very clear point to make distinction between this and the present new species.

\section{REFERENCES}

Borradaile, L.B. 1915. Notes on carides. Ann. Mag. nat. Hist., (8) 15: 205-213.

Holthuis, L.B. 1950. The Decapoda of the Siboga Expedition. Part X. The Palaemonidae collected by the Siboga and Snellius Expeditions with remarks on other species. I. Subfamily Palaemoninae. Siboga Exped., Monogr. 39 (a) (9): 1-268, figs. 1-52.

1952. The Decapoda of the Siboga Expedition. Part XI. The Palaemonidae collected by the Siboga and Snellius Expeditions with remarks on other species. II. Subfamily Pontoniinae. Siboga Exped., Monogr. 39 (a) (10): 1-253, figs. 1-110, 1 tab.

Kemp, S. 1922. Notes on Crustacea Decapoda in the Indian Museum. XV. Pontoniinae. Rec. Indian Mus., 24 (2): 113-288, figs. 1-105, pls. 3-9. 